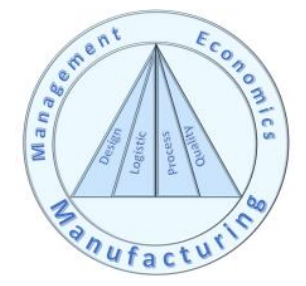

International Journal of Manufacturing Economics and Management

ISSN 2784-1278 ISSN-L 2784-1278, Vol. I, No. 2 / 2021

https://doi.org/10.54684/ijmem.2021.1.2.41

\title{
PLANNING AND SCHEDULE OF MAINTENANCE WORKS FOR INJECTION MACHINES
}

\author{
Ramona-Iuliana Popa ${ }^{1}$, Maria Catana ${ }^{1}$, Gabriel Cimpoesu ${ }^{1}$, \\ Lucian Burlea ${ }^{2}$, Constantin Cărăușu ${ }^{1}$
}

\author{
1"Gheorghe Asachi” Technical University of Iasi-Romania, Department of Machine Manufacturing Technology, \\ Blvd. Mangeron 59A, 700050, Iasi, Romania \\ 2"Grigore T. Popa" University of Medicine and Pharmacy of Iasi, Universitatii Street, 16, 700115, Iasi, Romania
}

Corresponding author: Constantin Cărăușu, constantin.carausu@academic.tuiasi.ro

\begin{abstract}
Keeping the equipment and machinery in working order is a very important activity in the field of industrial production, being specific to the maintenance department within an enterprise. Ensuring an optimal in operation of the manufacturing systems is closely related to the prevention of defects, an action that must be found in a planning and scheduling of preventive-planned maintenance works. In the paper, in addition to the introductory part on the main objectives and implementation of the maintenance system and maintenancespecific operations, a case study is conducted for the planning and organization of maintenance in a company equipped with plastic injection machines. The main stages developed consisted in elaborating the maintenance plan, establishing the optimal moment for replacing the machine tools, choosing the optimal type of machine tool and establishing the elements of random wear of the machine tools. It is concluded that the optimal type of injection molding machine that will be chosen to replace the $T_{10}$ injection molding machine is $T_{14}$, because it has a minimum average cost of acquisition, maintenance and repair, respectively $42.286 \mathrm{UV}$.
\end{abstract}

\section{INTRODUCTION}

The introduction of a plastic material in a molten state under pressure in the mold where its cooling and solidification takes place, in order to obtain a product, is called injection. Injection is a highly productive process by which products, generally of high complexity, can be obtained from both plastics and biodegradable materials. Globally, there are many research results based on the plastic injection process and, to a much lesser extent, results for the injection of biodegradable materials. The main advantage of obtaining landmarks by injection from biodegradable material is a low energy consumption, given the melting temperature for these biodegradable materials, [1,2]. Taking into account all these mentioned aspects, even more so the periodic functional maintenance of preventive-planned type is of vital importance in the machine building industry, and the planning and scheduling of these activities must be done rigorously. Sometimes, this activity is interposed between the system of recurrent functional maintenance and that of technical revisions.

Preventive-planned maintenance has as main purpose the knowledge with a certain time before the parts or subassemblies that need to be replaced, knowledge that leads to a substantiation of the necessary stocks with spare parts, based on some calculations and economic indicators. Maintenance operations can be corrective or preventive. The main objectives of preventive-planned maintenance are presented in Figure 1.

The preventive-planned maintenance system has distinct specific operations, as follows:

-periodic verification of fixed assets, operation with the definite purpose of detecting in due time the occurrence of accidental defects or malfunctions of the equipment, and is performed on groups of machine tools or on technological lines. This operation takes place without stopping the equipment or with a very short stop, depending on the complexity of the possible defect to be detected. Adjustments, vibrations, and accuracy in operation are remedied by this operation; 


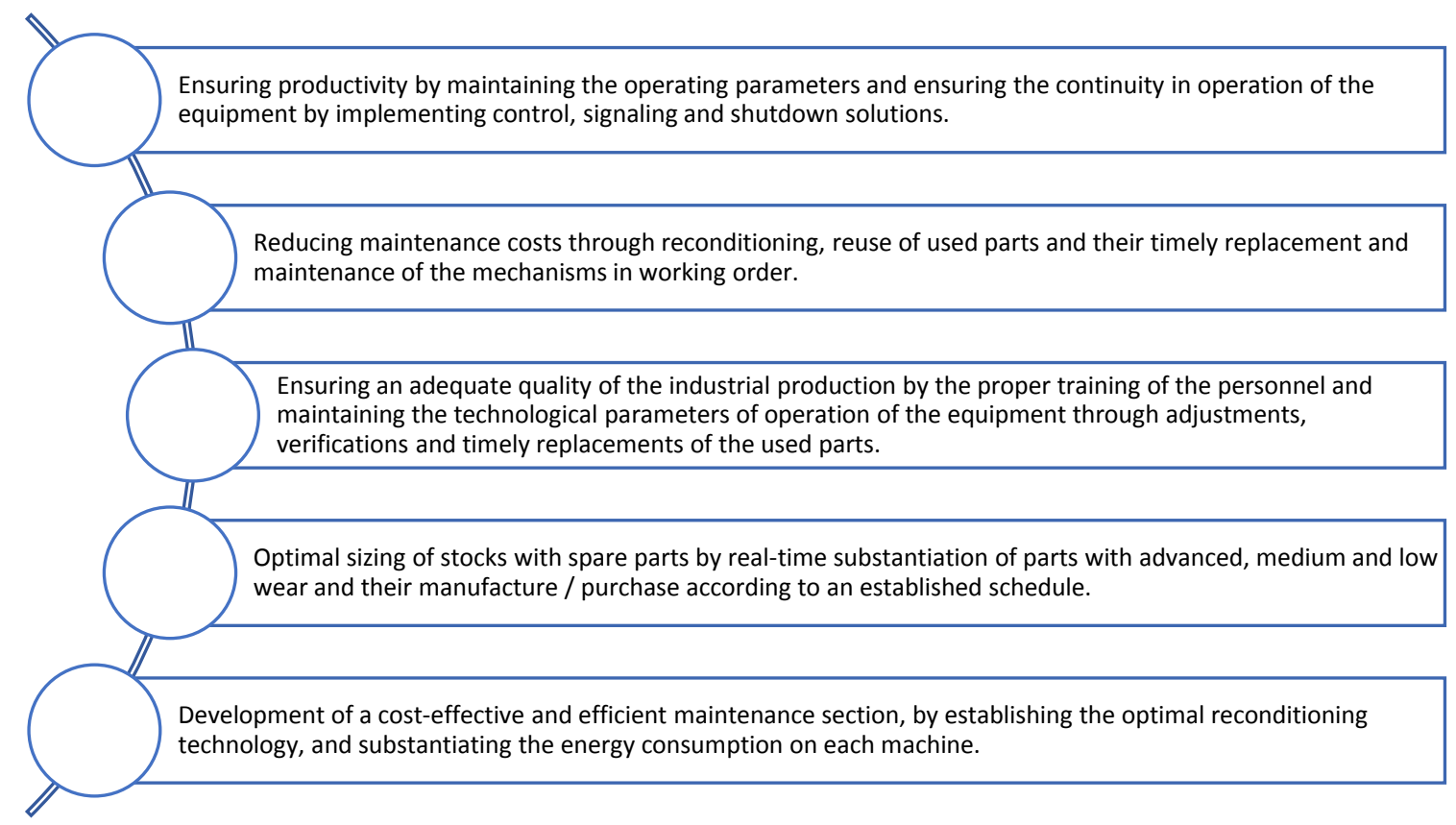

Fig.1. Main objectives and implementation methods of preventive-planned maintenance

-partial revision, consists in a careful examination of the operation of the parts, subassemblies and assemblies regarding the degree of assurance of the processing precision and of the safety in operation. The operation is performed on subassemblies and assemblies by disassembly, adjustment, replacement of worn parts and reconditioning, in order to reduce abnormal noise in operation or other deficiencies. This overhaul will be planned only during the technological breaks without the production being affected;

- the general revision aims at the verification in detail of the functional assemblies in order to ensure a safety in operation and an appropriate precision. The operation aims to check the entire machine tool, machinery or equipment in order to remedy any defects by reconditioning or replacing used parts. The operation is performed by disassembly, cleaning, measurement and verification, after which the replacements or repairs take place and, finally, the current adjustments are made;

- the technical quality control is necessary to be performed after the partial and general revisions, with the clearly defined purpose of ascertaining or not the precision and safety in operation of the equipment, maintaining the adjustments in time and the deviations from the quality of the parts.

The preventive-planned maintenance system, in addition to increasing productivity due to the normal operation of machine tools, production lines, etc., reduces repair costs and makes the human operator responsible for the importance of this activity.

The efficiency of the organization of the maintenance system of the equipment and installations can be influenced by a series of technical, economic and organizational factors. From a technical point of view, the operation of the equipment is the main factor, the technologies chosen for repairs, the costs of overhauls can be factors of economic nature and the way of organizing production, organizing the work process can be constituted as factors of organizational nature. In terms of a direct influence on the organization of the maintenance system, the following factors can have a significant influence:

-observance of the technical norms in force regarding the operation and maintenance of the equipment; -use of normal operating regimes;

- the use of additional accessories on machine tools in order to reduce the physical effort made by the operators and to increase the labor productivity;

-existence of a plan to ensure the rhythmicity of maintenance activities.

Maintenance systems can be preventive and corrective. Preventive maintenance systems can be systemic and conditioned, and corrective ones can be curative and palliative. [4]

The main strategies of maintenance systems are:

-organizing own maintenance activities involves a certain orientation of investments, restriction or concentration of certain activities;

- the subcontracting of the maintenance activity must be based on a technical-economic substantiation in order to justify the economic efficiency in the situation of adopting such a strategy;

- the acquisition of new technical systems means big reductions in terms of maintenance costs and the possibility of directing investments to other directions. 


\section{INJECTION MACHINE MAINTENANCE SYSTEM}

Plastics injection machines are machines that include mechanical, electrical and hydraulic equipment, which means that the maintenance of these machines is a complex process. Ensuring a properly planned preventive maintenance system leads to an increase in the lifespan and availability of machines and to an increase in productivity.

In order to implement the maintenance system in the field of plastics injection, it is necessary to go through the operations presented in Figure 2, [3]. In addition to the eight operations presented, it is important to periodically check the noise sources, which may come from blocked hydraulic components or from an inadequate amount of oil in the machine tool.

\begin{tabular}{|c|c|}
\hline Choosing quality oils & $\begin{array}{l}\text { - Quality oils allow superior lubrication; } \\
\text { - Quality oils reduce the risk of malfunctions and wear of injection molding machines. }\end{array}$ \\
\hline $\begin{array}{l}\text { Periodically clean or } \\
\text { change the oil filters }\end{array}$ & $\begin{array}{l}\text { - Oil filters ensure the proper operation of injection machines; } \\
\text { - It is recommended to change once every three months. }\end{array}$ \\
\hline $\begin{array}{l}\text { Cleaning fans and } \\
\text { cooling systems }\end{array}$ & $\begin{array}{l}\text { - Fans and cooling systems ensure the proper functioning of the machines; } \\
\text { - It is recommended to change them every two years. }\end{array}$ \\
\hline $\begin{array}{l}\text { Periodic inspection of } \\
\text { electrical system }\end{array}$ & $\begin{array}{l}\text { - It is recommended to check the engine, the heating tube and the thermocouple; } \\
\text { - This check is recommended once a year. }\end{array}$ \\
\hline $\begin{array}{l}\text { Carrying out a daily } \\
\text { verification plan }\end{array}$ & $\begin{array}{l}\text { - Checking the operating system manually, semi-automatically and automatically; } \\
\text { - Checking the operation of all functions in the control panel. }\end{array}$ \\
\hline $\begin{array}{l}\text { Periodic check of the oil } \\
\text { level in the hydraulic tank }\end{array}$ & $\begin{array}{l}\text { - Check the tank to avoid accidental leaks; } \\
\text { - Checking the correct lubrication of the equipment. }\end{array}$ \\
\hline $\begin{array}{l}\text { Checking the pressure in } \\
\text { the hydraulic system }\end{array}$ & $\begin{array}{l}\text { - Periodic pressure check; } \\
\text { - Remedy situations in which the pressure is low or too high. }\end{array}$ \\
\hline $\begin{array}{l}\text { Checking the oil and } \\
\text { cooling system }\end{array}$ & $\begin{array}{l}\text { - Checking for changes in oil pressure and viscosity; } \\
\text { - Remedying situations so as not to affect productivity. }\end{array}$ \\
\hline
\end{tabular}

Fig.2. Operations of the preventive-planned maintenance system for plastics injection machines, [3]

\section{CASE STUDY REGARDING THE ORGANIZATION OF THE MAINTENANCE SECTION}

In order to organize the maintenance section at a unit producing plastic products by injection, the following steps are necessary:

-analysis of the existing situation;

-elaboration of the maintenance plan;

-establishing the optimal moment to replace the machine tools;

-choosing the optimal type of machine tool;

-establishing the wear elements of the machine tools.

The management of the company producing plastic parts by injection according to the interruptions registered in the operation of the injection machines, has as main objective the increase of the productivity by increasing the number of injection machines to be involved in the production process. Thus, the management of the unit also requests the maintenance department to elaborate a maintenance strategy in order to achieve, together with the other sections of the enterprise, this objective.

The situation existing at time $t$ in the enterprise regarding the stationary period due to the failure on each injection machine is presented in Table 1.

Naturally, after setting the goal, we move on to establishing / adopting the maintenance method that will be used. The team in the maintenance department, taking into account the experience gained, proposed the rational method of maintenance, for the implementation of which the following rules must be observed: to be available and sufficient the necessary information; to make a quantitative and qualitative selection and to rationally adapt the means to the existing requirements.

The ABC method, also known as Law 80-20, is frequently assimilated to Paretto's law and consists of dividing an ensemble into three classes, A (elements with a weight of 80\%), B (elements with a weight of 15\%), and C (5\% share), [5]. 
Table 1. The situation existing at time $t$ in the enterprise

\begin{tabular}{|c|c|c|c|}
\hline No.crt. & $\begin{array}{c}\text { Injection molding } \\
\text { machine type }\end{array}$ & Interruption period, $[\mathrm{h}]$ & Number of interruptions \\
\hline 1 & $\mathrm{~T}_{1}$ & 105 & 2 \\
\hline 2 & $\mathrm{~T}_{2}$ & 5 & 3 \\
\hline 3 & $\mathrm{~T}_{3}$ & 15 & 5 \\
\hline 4 & $\mathrm{~T}_{4}$ & 20 & 4 \\
\hline 5 & $\mathrm{~T}_{5}$ & 13 & 2 \\
\hline 6 & $\mathrm{~T}_{6}$ & 8 & 7 \\
\hline 7 & $\mathrm{~T}_{7}$ & 150 & 6 \\
\hline 8 & $\mathrm{~T}_{8}$ & 41 & 6 \\
\hline 9 & $\mathrm{~T}_{9}$ & 9 & 5 \\
\hline 10 & $\mathrm{~T}_{10}$ & 185 & 4 \\
\hline 11 & $\mathrm{~T}_{11}$ & 25 & 7 \\
\hline 12 & $\mathrm{~T}_{12}$ & 7 & 4 \\
\hline 13 & $\mathrm{~T}_{13}$ & 3 & 5 \\
\hline 14 & $\mathrm{~T}_{14}$ & 95 & 2 \\
\hline 15 & $\mathrm{~T}_{15}$ & 4 & 7 \\
\hline
\end{tabular}

In order to apply the $\mathrm{ABC}$ method, a classification of all faults is made in descending order according to the parking time, each fault being related to a certain injection machine, the data being presented systematically in Table 2. Figure 3 showed the share of stationary on each machine tool of the total parking times per unit. The zones A, B, C and the cars grouped on each zone are highlighted.

Table 2. Centralizing data required for the application of the ABC method

\begin{tabular}{|c|c|c|c|c|c|c|c|}
\hline $\begin{array}{c}\text { Injection } \\
\text { molding } \\
\text { machine } \\
\text { type }\end{array}$ & $\begin{array}{c}\text { Interruption } \\
\text { period, }[\mathrm{h}]\end{array}$ & $\begin{array}{c}\text { Cumulative } \\
\text { interruption } \\
\text { period, }[\mathrm{h}]\end{array}$ & $\%$ & $\begin{array}{c}\text { Number of } \\
\text { interruptions }\end{array}$ & $\begin{array}{c}\text { Number of } \\
\text { cumulative } \\
\text { interruptions }\end{array}$ & $\%$ & Zone \\
\hline $\mathrm{T}_{10}$ & 185 & 185 & 27 & 4 & 4 & 6.15 & \\
\hline $\mathrm{T}_{7}$ & 150 & 335 & 48.90 & 8 & 12 & 18.46 & \multirow{2}{*}{ A } \\
\hline $\mathrm{T}_{1}$ & 105 & 440 & 64.23 & 2 & 14 & 21.53 & \\
\hline $\mathrm{T}_{14}$ & 95 & 535 & 78.10 & 5 & 19 & 29.23 & \\
\hline $\mathrm{T}_{8}$ & 41 & 576 & 84.08 & 6 & 25 & 38.46 & \\
\hline $\mathrm{T}_{11}$ & 25 & 601 & 87.73 & 4 & 29 & 44.61 \\
\hline $\mathrm{T}_{4}$ & 20 & 621 & 90.66 & 4 & 33 & 50.77 & \multirow{2}{*}{$\mathrm{B}$} \\
\hline $\mathrm{T}_{3}$ & 15 & 636 & 92.84 & 5 & 38 & 58.46 & \\
\hline $\mathrm{T}_{5}$ & 13 & 649 & 94.74 & 2 & 40 & 61.54 & \\
\hline $\mathrm{T}_{9}$ & 9 & 658 & 95.05 & 6 & 46 & 70.77 & \\
\hline $\mathrm{T}_{6}$ & 8 & 666 & 97.22 & 3 & 49 & 75.38 & \\
\hline $\mathrm{T}_{12}$ & 7 & 673 & 98.24 & 7 & 56 & 86.15 \\
\hline $\mathrm{T}_{2}$ & 5 & 678 & 98.97 & 3 & 59 & 90.77 \\
\hline $\mathrm{T}_{15}$ & 4 & 682 & 99.56 & 2 & 61 & 93.84 \\
\hline $\mathrm{T}_{13}$ & 3 & 685 & 100 & 4 & 65 & 100 & \\
\hline
\end{tabular}

Using the data in Table 2, the ABC curve can be drawn, Figure 3, which highlights the connection between the cumulative downtime and the cumulative failures.

As you can see, the curve has three areas:

- zone A: $29.23 \%$ of failures represent $78.10 \%$ of the total downtime of the injection machines;

-zone B: $32.31 \%$ of the defects found represent only $16.64 \%$ of the total downtime of the injection machines;

-zone C: $38.46 \%$ of the faults found represent only $5.26 \%$ of the downtime of the injection machines. 


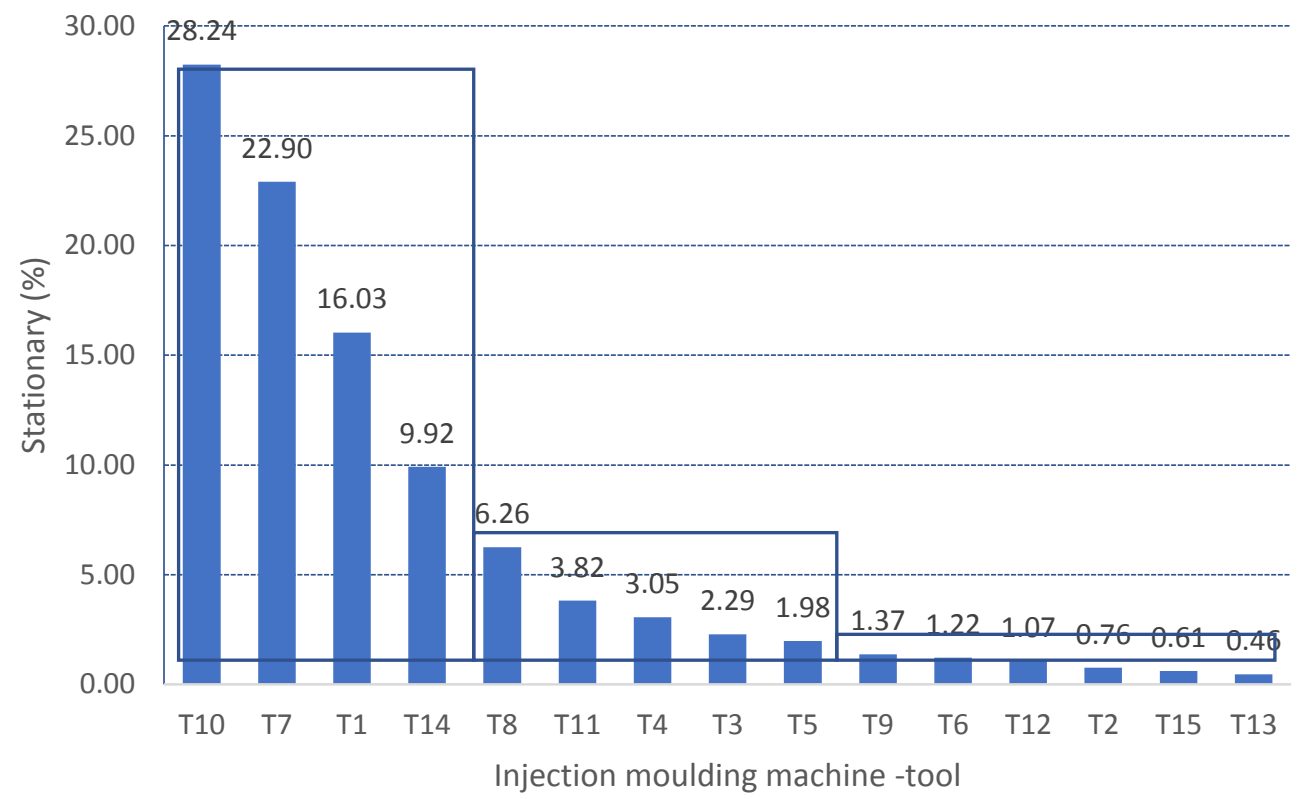

Fig. 3. Share of parking times per machine tool out of total parking times per unit

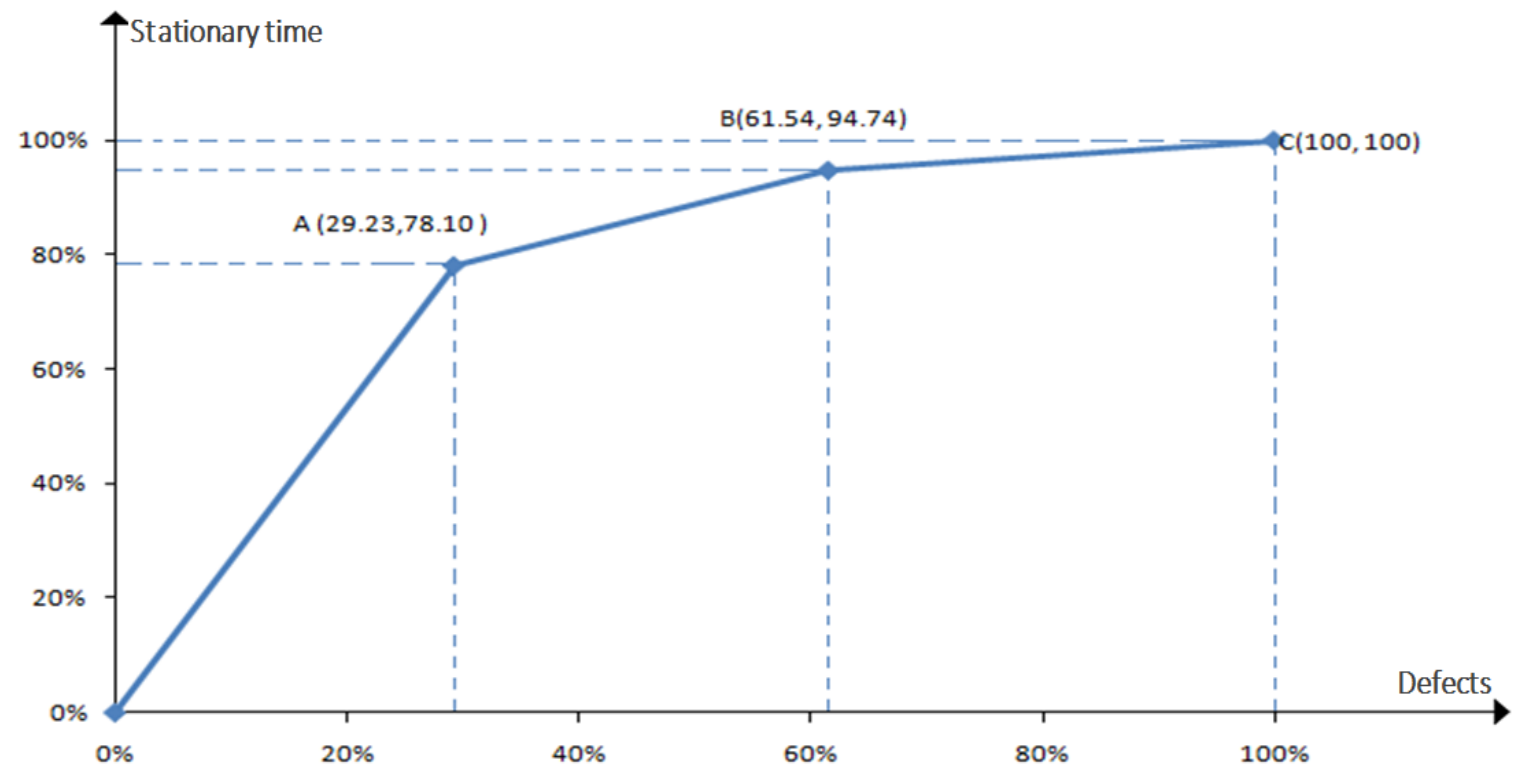

Fig. 4. Stationary time variation curve by applying the ABC method

According to the results obtained, some decisions can be made regarding the maintenance activity, as follows: -injection machines $T_{10}, T_{7}, T_{1}$ şi $T_{14}$, belong to A zone, have fundamental priority; for these machines a preventive-planned maintenance policy will be implemented, with a rigorous supervision of the "critical points";

-in case of injection machines from B zone $\left(T_{8}, T_{11}, T_{4}, T_{3}, T_{5}\right.$, ) no high level requirements will be imposed in terms of prevention methods;

- for injection molding machines from $\mathrm{C}$ zone $\left(T_{9}, T_{6}, T_{12}, T_{2}, T_{15}, T_{13}\right)$ no preventive maintenance method will be applied, but only maintenance actions according to needs.

Implementation of a method of preventive-planned maintenance of equipment $T_{10}, T_{7}, T_{1}$ and $T_{14}$, with direct effects on reducing or even eliminating accidental malfunctions, it will help increase the availability of injection molding machines by up to $78.10 \%$.

\subsection{Elaboration of the maintenance plan of the injection machines}

In order to elaborate the maintenance plan for the injection machine $\boldsymbol{T}_{10}$, taking into account the technical regulations for maintenance, the data in Table 3 are required for a three-shift operating regime. 
Table 3. Data necessary for the implementation of the maintenance plan

\begin{tabular}{|c|c|c|c|c|c|}
\hline $\begin{array}{l}\text { Category } \\
\text { number of } \\
\text { intervention }\end{array}$ & $\begin{array}{l}\text { The interval } \\
\text { between two } \\
\text { category } \\
\text { interventions } i\end{array}$ & $\begin{array}{l}\text { Standing time in } \\
\text { repairs (working } \\
\text { days) }\end{array}$ & $\begin{array}{l}\text { Planned costs, } \\
\text { (\% of total })\end{array}$ & $\begin{array}{l}\text { Completion date } \\
\text { type and } \\
\text { number, in the } \\
\text { general structure } \\
\text { of the repair } \\
\text { cycle, of the last } \\
\text { repair in the } \\
\text { current year }\end{array}$ & $\begin{array}{c}\text { Planned } \\
\text { operating mode } \\
\text { of the injection } \\
\text { molding } \\
\text { machine }\end{array}$ \\
\hline 1 & $\begin{array}{l}\text {-for } \mathrm{R}_{\mathrm{t}}-1150 \\
\text { hours; }\end{array}$ & -for $\mathrm{R}_{\mathrm{t}}-1$ day; & -for $\mathrm{R}_{\mathrm{t}}-1.5 \%$ & \multirow{4}{*}{$\begin{array}{l}\text { October } 20 \text { - } \\
\text { Fourth } \\
\text { Technical } \\
\text { Review }\end{array}$} & \multirow{4}{*}{$\begin{array}{l}-2 \text { work shifts; } \\
\text {-the duration of } \\
\text { the shift is } \\
\text { eight hours. }\end{array}$} \\
\hline 2 & $\begin{array}{l}\text {-for } \mathrm{R}_{\mathrm{C} 1}-2300 \\
\text { hours; }\end{array}$ & -for $\mathrm{R}_{\mathrm{Cl} 1}-5$ days; & -for $\mathrm{R}_{\mathrm{C} 1}-12.5 \%$, & & \\
\hline 3 & $\begin{array}{l}\text {-for } \quad \mathrm{R}_{\mathrm{C} 2}-9200 \\
\text { hours; }\end{array}$ & -for $\mathrm{R}_{\mathrm{C} 2}-11$ days; & -for $\mathrm{R}_{\mathrm{C} 2}-26 \%$ & & \\
\hline 4 & $\begin{array}{l}\text {-for } R_{K}-27600 \\
\text { hours; }\end{array}$ & -for $R_{K}-20$ days; & -for $\mathrm{R}_{\mathrm{K}}-60 \%$ & & \\
\hline
\end{tabular}

The stages of elaboration of the maintenance plan are as follows:

a) Determining the number of technical interventions (by categories) to be performed within a repair cycle, using relation (1), with the values presented in Table 4.

$\mathrm{Ni}=\frac{\mathrm{D}_{\mathrm{CR}}}{\mathrm{d}_{\mathrm{i}}}-\mathrm{N}_{\mathrm{i}}^{\mathrm{S}}$

where: $\mathrm{N}_{\mathrm{i}}$ represents the number of category $i$ interventions; $\mathrm{D}_{\mathrm{CR}}$ is the duration of the repair cycle, [h]; $\mathrm{d}_{\mathrm{i}}$ is the interval between two category $i$ interventions, and $N_{i}^{S}$ represents the number of higher degree interventions.

Table 4. Calculated values of technical interventions

\begin{tabular}{|c|c|c|}
\hline No.crt. & Name of technical intervention & Value obtained \\
\hline 1 & $\mathrm{~N}_{\mathrm{RK}}$ & 1 \\
\hline 2 & $\mathrm{~N}_{\mathrm{RC} 2}$ & 2 \\
\hline 3 & $\mathrm{~N}_{\mathrm{RC} 1}$ & 9 \\
\hline 4 & $\mathrm{~N}_{\mathrm{Rt}}$ & 12 \\
\hline
\end{tabular}

b) Graphic representation of the structure of the repair cycle based on the number of interventions previously determined and the duration between two interventions of the same kind, according to Figure 5.

c) Establishing the time interval (T1) in the calendar days, from the date of the last intervention performed on the T10 injection machine in the base year until each of the following interventions in the structure of the repair cycle, using relation (2).

$\mathrm{T}_{\mathrm{i}}=\left[\frac{D_{R C} \cdot n}{d_{s} \cdot n_{s}}+\sum_{i=1}^{n-1} t_{s i}\right] \cdot K_{t}$,

where: $D_{R C}$ is the operating interval between two consecutive interventions (interval between two technical revisions), [h]; $d_{s}$ represents the planned duration of the exchange; $n_{s}$ is the number of shifts; $n$ is the number of the intervention for which the total downtime of the injection machine is calculated in the previous planned interventions, in working days, according to the norm, $\mathrm{T}_{\mathrm{i}}$, given by the relation (3).

$\mathrm{T}_{\mathrm{i}}=\sum_{i=1}^{n-1} t_{s i}$

where $\mathrm{t}_{\mathrm{si}}$ it is the stationary time for the $i$ intervention and $\mathrm{K}_{\mathrm{t}}$ coefficient of transformation from actual operating days into calendar days given by the relation (4). 
$\begin{array}{llllllllllllllllllllllllll}\mathrm{R}_{1} & \mathrm{R}_{1} & \mathrm{R}_{1} & \mathrm{R}_{1} & \mathrm{R}_{1} & \mathrm{R}_{1} & \mathrm{R}_{1} & \mathrm{R}_{1} & \mathrm{R}_{2} & \mathrm{R}_{1} & \mathrm{R}_{1} & \mathrm{R}_{1} & \mathrm{R}_{1} & \mathrm{R}_{1} & \mathrm{R}_{1} & \mathrm{R}_{1} & \mathrm{R}_{2} & \mathrm{R}_{1} & \mathrm{R}_{1} & \mathrm{R}_{1} & \mathrm{R}_{1} & \mathrm{R}_{1} & \mathrm{R}_{1} & \mathrm{R}_{1} & \mathrm{R}_{2}\end{array}$

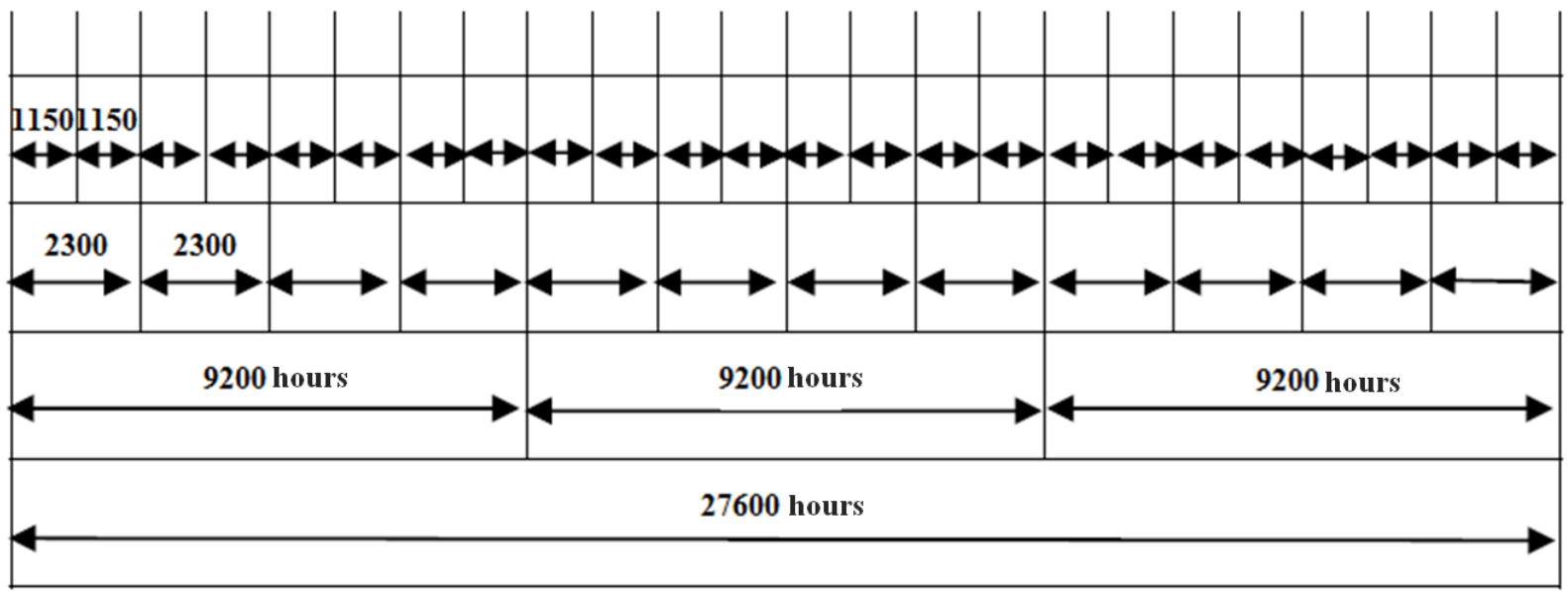

Fig. 5. The structure of the repair cycle

In case of $T_{10}$ injection moulding machine the following interventions are: $R_{C 2}, R_{t}, R_{C 1}, R_{k}$.

$\mathbf{T}_{1}=\left[\frac{1150 \cdot 1}{8 \cdot 2}+0\right] \cdot 1.43=\mathbf{1 0 3}$ days

$\mathbf{T}_{2}=\left[\frac{1150 \cdot 2}{8 \cdot 2}+11\right] \cdot 1.43=\mathbf{2 2 1}$ days

$\mathbf{T}_{3}=\left[\frac{1150 \cdot 3}{8 \cdot 2}+(11+1)\right] \cdot 1.43=\mathbf{3 2 6}$ days

$\mathbf{T}_{4}=\left[\frac{1150 \cdot 4}{8 \cdot 2}+(11+1+5)\right] \cdot 1.43=435$ days

d) The calendar schedule of the planned technical interventions is presented in Table 5. So, for the $\mathrm{T}_{10}$ injection machine in the plan year, the following technical interventions will be performed: two technical revisions $\left(\mathrm{R}_{\mathrm{t}}\right)$; a current grade I repair $\left(\mathrm{R}_{\mathrm{C} 1}\right)$ and a current grade II repair $\left(\mathrm{R}_{\mathrm{C}} 2\right)$.

e) Determining the expenditure budget for carrying out the planned technical interventions.

In the case of the $\mathrm{T}_{10}$ injection machine, whose inventory value is $150.000 \mathrm{UV}$ (value units), the repair costs, by type of technical intervention, will be:

- for a technical overhaul $\left(\mathrm{R}_{\mathrm{t}}\right): 150000 \cdot 1.5 \%=2250 \mathrm{UV}$;

- for a current grade I repair $\left(\mathrm{R}_{\mathrm{C} 1}\right): 150000 \cdot 9 \%=13500 \mathrm{UV}$;

- for a current grade II repair $\left(\mathrm{R}_{\mathrm{C} 2}\right): 150000 \cdot 26 \%=39000 \mathrm{UV}$;

- for a major overhaul $\left(\mathrm{R}_{\mathrm{K}}\right): 150000 \cdot 60 \%=90000 \mathrm{UV}$.

Considering the technical interventions planned for the plan year, it results that this year the expenses with the repairs of the $\mathrm{T}_{10}$ machine will be $2 \cdot 2250+13500+39000=57000 \mathrm{UV}$.

Table 5. Scheduling of planned technical interventions

\begin{tabular}{|c|c|c|c|c|c|c|c|c|c|c|c|c|c|c|c|c|}
\hline \multirow{2}{*}{$\begin{array}{c}\text { Year } \\
\text { Indicator }\end{array}$} & \multicolumn{4}{|c|}{ Basic } & \multicolumn{12}{|c|}{ Plan } \\
\hline & IX & $X$ & XI & XII & I & II & III & IV & V & VI & VII & VIII & IX & $X$ & XI & XII \\
\hline $\begin{array}{l}\text { Number of } \\
\text { calendar } \\
\text { days }\end{array}$ & 10 & 31 & 30 & 31 & 31 & 28 & 31 & 30 & 31 & 30 & 31 & 31 & 30 & 31 & 30 & 31 \\
\hline $\begin{array}{c}\text { Cumulated } \\
\text { number of } \\
\text { days }\end{array}$ & 10 & 41 & 71 & 102 & 133 & 161 & 192 & 222 & 253 & 283 & 314 & 345 & 375 & 406 & 436 & 467 \\
\hline $\begin{array}{c}\text { Planned } \\
\text { technical } \\
\text { interventions }\end{array}$ & & & & & $\mathrm{R}_{\mathrm{C} 2}$ & & & $\mathrm{R}_{\mathrm{t}}$ & & & & $\mathrm{R}_{\mathrm{C} 1}$ & & & $\mathrm{R}_{\mathrm{t}}$ & \\
\hline
\end{tabular}




\subsection{Determining the optimal time to replace machine tools}

In order to determine the optimal time to replace an injection machine, the A model. Kaufman can be used, [6] a model that takes into account the maintenance and repair costs, the purchase value of the machine, considering as the optimal time to replace the year in which the maintenance and repair costs exceed the discounted cost of acquisition, maintenance and repair, respectively the year in which the relationship is satisfied (5).

$\mathrm{Ch}_{\mathrm{n}+1}>\frac{A+\sum_{j=1}^{n} C h^{j-1} j}{\sum_{j=1}^{n} y_{j-1}}$

where: $\mathrm{A}$ is the expenses of machine purchase; $\mathrm{Ch}_{\mathrm{j}}$ are the expenses for the maintenance and repair of the machine in year $j$, and $\mathrm{y}=\frac{1}{1+d}$, is the updating factor, woth „d" percentage of interest and taxes.

Analyzing the "history" of the $\mathrm{T}_{10}$ injection machine, existing in the company, it turns out that it was put into operation seven years ago, the normal duration of operation being 10 years, and the maintenance and repair costs were: year 1 - $4000 \mathrm{UV}$, year 2 - $8500 \mathrm{UV}$, year 3 - $14000 \mathrm{UV}$, year 4 - $21500 \mathrm{UV}$, year 5 - $27000 \mathrm{UV}$, year 6 - $36000 \mathrm{UV}$ and year 7 - $41000 \mathrm{UV}$.

Considering the maintenance and repair plan developed, the level of these expenses is $57000 \mathrm{UV}$, the expenses occasioned by the purchase of the $\mathrm{T}_{10}$ machine are $150000 \mathrm{UV}$, and the interests and taxes represent $8 \%$.

Thus, in order to determine the time of replacement of the $\mathrm{T}_{10}$ injection machine, according to relation (5), the systematization of the results is presented in Table 6 . It results that the $T_{10}$ injection machine will be replaced in the plan year, because the planned repair costs are higher than purchase plus up-to-date maintenance and repairs.

Table 6. Injection machine maintenance and repair costs $\mathrm{T}_{10}$

\begin{tabular}{|c|c|c|c|c|c|c|}
\hline Year & $\mathrm{Ch}_{\mathrm{j}}$ & $\alpha^{j-1}$ & $\sum_{j=1}^{n} y^{j-1}$ & $\sum_{j=1}^{n} C h_{j}^{y^{j-1}}$ & $A+\sum_{\mathrm{j}=1}^{\mathrm{n}} \mathrm{Ch}_{\mathrm{j}}^{\mathrm{j}^{\mathrm{j}-1}}$ & $\frac{A+\sum_{\mathrm{j}=1}^{\mathrm{n}} \mathrm{Ch}_{\mathrm{j}}^{\mathrm{y}^{\mathrm{j}-1}}}{\sum_{j=1}^{n} y^{j-1}}$ \\
\hline 1 & 4.500 & 1 & 1 & 4.500 & 150.000 & 150.000 \\
\hline 2 & 9.000 & 0.91 & 1.91 & 12.690 & 162.690 & 85.178 \\
\hline 3 & 14.500 & 0.83 & 2.74 & 24.725 & 174.725 & 63.768 \\
\hline 5 & 22.000 & 0.75 & 3.49 & 41.225 & 191.225 & 54.792 \\
\hline 6 & 27.500 & 0.69 & 4.18 & 60.200 & 210.200 & 48.287 \\
\hline 7 & 46.500 & 0.64 & 4.82 & 83.560 & 233.560 & 47.773 \\
\hline 8 & 57.000 & 0.57 & 5.39 & 107.500 & 257.500 & 48.503 \\
\hline
\end{tabular}

\subsection{Choosing the optimal type of injection molding machine}

To replace the $T_{10}$ machine it is possible to choose a new machine from four types of machines $\left(T_{t 1}, T_{t 2}, T_{t 3}\right.$, and $\mathrm{T}_{\mathrm{t} 4}$ ), with the same performance from a technical point of view, but with different purchase prices and maintenance and repair costs, according to the Table 7.

The choice of the optimal type of injection machine will be made based on the economic criterion (relation 6), considering as the optimal type that injection machine for which the purchase, maintenance and repair for a certain period is minimal.

$\mathrm{C}_{\mathrm{m}}=\frac{1}{n \cdot m} \cdot \sum_{i=1}^{n}\left(A_{i}+\sum_{j=1}^{m} C h_{i j}\right)$

where: $\mathrm{C}_{\mathrm{m}}$ is the average cost of purchasing, maintaining and repairing the injection molding machine, [UV]; These are the costs of purchasing the machine; $\mathrm{C}_{\text {hij }}$ represents the maintenance and repair costs of the purchased equipment and related to the maintenance and repair cycles $j ; \mathrm{n}$ is the number of machine purchases during the period considered, and $\mathrm{m}$ is the number of maintenance and repair cycles between two replacements.

The values obtained for the average $C_{m}$ costs for each type of injection molding machine are summarized in Table 8.

The optimal type of injection machine that will be chosen to replace the $T_{10}$ injection machine is $T_{t 4}$, because it has a minimum average cost of purchase, maintenance and repair, respectively $42.286 \mathrm{UV}$. 
Table 7. Expenses for the purchase of new injection machines

\begin{tabular}{|c|c|c|c|c|c|c|c|c|c|}
\hline \multirow{2}{*}{$\begin{array}{c}\text { Injection } \\
\text { machine } \\
\text { type }\end{array}$} & $\begin{array}{c}\text { Purchase } \\
\text { expenses, } \\
{[\mathrm{UV}]}\end{array}$ & \multicolumn{10}{|c|}{ Maintenance and repair costs } \\
\cline { 3 - 12 } & 1 cycle & 2 cycle & 3 cycle & 4 cycle & 5 cycle & 6 cycle & 7 cycle & 8 cycle \\
\hline \multirow{2}{*}{$\mathrm{T}_{\mathrm{t} 1}$} & 105.000 & 6.500 & 8.500 & 11.500 & - & - & - & - & - \\
\cline { 2 - 11 } & 120.000 & - & - & - & 8.500 & 11.000 & 14.000 & - & - \\
\hline $\mathrm{T}_{\mathrm{t} 2}$ & 175.000 & 8.500 & 10.000 & 13.000 & 15.000 & 17.500 & 20.000 & - & - \\
\hline \multirow{2}{*}{$\mathrm{T}_{\mathrm{t} 3}$} & 145.000 & 7.000 & 8.500 & 13.000 & 15.500 & - & - & - & - \\
\cline { 2 - 11 } & 160.000 & - & - & - & - & 8.000 & 10.500 & 13.000 & 16.500 \\
\hline $\mathrm{T}_{\mathrm{t} 4}$ & 185.000 & 9.000 & 11.000 & 13.500 & 16.500 & 18.500 & 20.500 & 22.000 & - \\
\hline
\end{tabular}

Table 8. Average $\mathrm{C}_{\mathrm{m}}$ costs of acquisition, maintenance and repair

\begin{tabular}{|c|c|c|}
\hline No.crt. & Average cost per type of injection molding machine & Value, [UV] \\
\hline 1 & $\mathrm{CmT}_{\mathrm{t} 1}=\frac{1}{2 \cdot 3}\left[\begin{array}{c}(105000+(6500+8500+11500)+120000+ \\
(8500+11000+14000)]\end{array}\right.$ & 47500 \\
\hline 2 & $\mathrm{CmT}_{\mathrm{t} 2}=\frac{1}{1 \cdot 6}\left[\begin{array}{c}175000+(8500+10000+13000+15000+ \\
17500+20000)]\end{array}\right.$ & 43167 \\
\hline 3 & $\mathrm{CmT}_{\mathrm{t} 3}=\frac{1}{2 \cdot 4}[145000+(7000+8500+13000+15500)+$ & 49625 \\
& $160000+(8000+10500+13000+16500)]$ & \\
\hline 4 & $\mathrm{CmT}_{\mathrm{t} 4}=\frac{1}{1 \cdot 7}[185000+(9000+11000+13500+16500+$ \\
& $18500+20500+22000)]$ & 42286 \\
\hline
\end{tabular}

\subsection{Determining the random wear elements of the injection molding machine}

For $\mathrm{T}_{7}$ and $\mathrm{T}_{1}$ injection machines, whose interruptions represent $53.1 \%$ of the total time of enterprises in the section, in order to increase the availability of machines in the production section, the management of the maintenance section aims to study the behavior of a part of great importance for the operation of these injection machines, using the theory of random wear of industrial equipment.

Considering the "history" of these injection machines for a period of 10 years, existing in the enterprise, the situation of the remaining parts in operation is presented systematized in Table 9.

In order to make decisions about the supply and stock size for this part, it is necessary to calculate: survival function, probability of failure, conditional probability of failure, probability of having a replacement, respectively two replacements from 0 to 5 years and the average life of the piece. The values obtained are centralized in Table 10.

Table 9. History of injection molding machines in the enterprise

\begin{tabular}{|c|c|c|c|c|c|c|c|c|c|c|c|}
\hline t Year & $\begin{array}{c}0 \\
\text { (Number of } \\
\text { parts remaining } \\
\text { in operation) }\end{array}$ & 1 & 2 & 3 & 4 & 5 & 6 & 7 & 8 & 9 & 10 \\
\hline $\begin{array}{c}\text { Number of parts } \\
\text { remaining in } \\
\text { operation [n (t)] }\end{array}$ & 1100 & 1080 & 1040 & 980 & 910 & 640 & 320 & 270 & 210 & 140 & 0 \\
\hline
\end{tabular}


Table 10. Data for determining supply requirements and stock size

\begin{tabular}{|c|c|c|c|c|c|}
\hline Year & $\begin{array}{c}\text { Number } \\
\text { parts in } \\
\text { function } \\
{[\mathrm{n}(\mathrm{t})]}\end{array}$ & $\begin{array}{c}\text { Average life } \\
\mathrm{n}(\mathrm{t}-1)-\mathrm{n}(\mathrm{t})\end{array}$ & $\begin{array}{c}\text { Survival function } \\
\mathrm{V}(\mathrm{t})=\frac{\mathrm{n}(\mathrm{t})}{\mathrm{n}(0)}\end{array}$ & $\begin{array}{c}\text { Probability of failure } \\
\mathrm{p}(\mathrm{t})=\frac{\mathrm{n}(\mathrm{t}-1)-\mathrm{n}(\mathrm{t})}{\mathrm{n}(0)}\end{array}$ & $\begin{array}{c}\text { Conditional probability } \\
\text { of failure } \\
\mathrm{P}_{\mathrm{c}}(\mathrm{t})=\frac{\mathrm{n}(\mathrm{t}-1)-\mathrm{n}(\mathrm{t})}{\mathrm{n}(\mathrm{t}-1)}\end{array}$ \\
\hline 0 & 1000 & - & 1 & 0 & 0 \\
\hline 1 & 990 & 10 & 0.99 & 0.01 & 0.01 \\
\hline 2 & 930 & 60 & 0.93 & 0.06 & 0.06 \\
\hline 3 & 870 & 60 & 0.87 & 0.06 & 0.064 \\
\hline 4 & 820 & 50 & 0.82 & 0.27 & 0.329 \\
\hline 5 & 550 & 270 & 0.55 & 0.34 & 0.618 \\
\hline 6 & 210 & 340 & 0.21 & 0.05 & 0.238 \\
\hline 7 & 160 & 50 & 0.16 & 0.04 & 0.583 \\
\hline 8 & 120 & 40 & 0.12 & 0.07 & 1 \\
\hline 9 & 50 & 70 & 0.05 & 0.05 & \\
\hline 10 & 0 & 50 & 0 & & 0.05 \\
\hline
\end{tabular}

The probability of having a termination in the first " $t$ " years is determined by the relation (7).

$\mathrm{P}_{1}(\mathrm{t})=\sum_{u=1}^{t} v(t-u) \cdot f(u)$

where: $\mathrm{v}(\mathrm{t}-\mathrm{u})$ is the survival function, and $\mathrm{f}(\mathrm{u})$ is the probability of failure.

Based on the relation (7) and the data from Table 9, the probability of having a decommissioning in the first 5 years of operation is presented in Table 11.

Table 11. Probability of failure in the first 5 years of operation

\begin{tabular}{|c|c|c|}
\hline No.year & Probability every year & Value \\
\hline 1 & $\mathrm{P}_{1}(1)=\sum_{u=1}^{1} \mathrm{v}(1-\mathrm{u}) \cdot \mathrm{f}(\mathrm{u})=\mathrm{v}(0) \cdot \mathrm{f}(1)=1 \cdot 0.01$ & 0.01 \\
\hline 2 & $\begin{array}{c}\mathrm{P}_{1}(2)=\sum_{u=1}^{2} \mathrm{v}(2-\mathrm{u}) \cdot \mathrm{f}(\mathrm{u})=\mathrm{v}(1) \cdot \mathrm{f}(1)+\mathrm{v}(0) \cdot \mathrm{f}(2)=0.99 \\
0.01+1 \cdot 0.06\end{array}$ & 0.069 \\
\hline 3 & $\begin{array}{c}\mathrm{P}_{1}(3)=\sum_{u=1}^{3} \mathrm{v}(3-\mathrm{u}) \cdot \mathrm{f}(\mathrm{u})=\mathrm{v}(2) \cdot \mathrm{f}(1)+\mathrm{v}(1) \cdot \mathrm{f}(2)+\mathrm{v}(0) \cdot \mathrm{f}(3)= \\
0.93 \cdot 0.01+0.99 \cdot 0.06+1 \cdot 0.06\end{array}$ & 0.1287 \\
\hline 4 & $\begin{array}{c}P_{1}(4)=\sum_{u=1}^{4} v(4-u) \cdot f(u)=v(3) \cdot f(1)+v(2) \cdot f(2)+v(1) \cdot f(3)+ \\
v(0) \cdot f(4)=0.87 \cdot 0.01+0.93 \cdot 0.06+0.99 \cdot 0.06+1 \cdot 0.05\end{array}$ & 0.1739 \\
\hline 5 & $\begin{array}{c}P_{1}(5)=\sum_{u=1}^{5} v(5-u) \cdot f(u)=v(4) \cdot f(1)+v(3) \cdot f(2)+v(2) \cdot f(3)+ \\
v(1) \cdot f(4)+v(0) \cdot f(5)= \\
0.82 \cdot 0.01+0.87 \cdot 0.06+0.93 \cdot 0.06+0.99 \cdot 0.05+1 \cdot 0.27\end{array}$ & 0.4357 \\
\hline
\end{tabular}

In order to determine the probability of having " $m$ " outputs in the first " $t$ " years of operation, the recurrence relation is used (8).

$\mathrm{P}_{\mathrm{m}}(\mathrm{t})=\sum_{u=1}^{1} P_{m-1}(t-1) \cdot f(u)$, with condition: $\mathrm{P}_{\mathrm{m}}(0)=0$

Applying the relation (8), also based on the data from Table 11 and those obtained for the calculation of the probability of having a replacement in the range from 0 to 5 years, it will result :

$\mathrm{P}_{2}(5)=\sum_{u=1}^{1} P_{2-1} \cdot(5-1) \cdot f(2)=\mathrm{P}_{1}(4) \cdot f(1)+\mathrm{P}_{1}(3) \cdot f(2)+\mathrm{P}_{1}(2) \cdot f(3)+\mathrm{P}_{1}(1) \cdot f(4)=0.1739 \cdot 0.01+$

$0.1287 \cdot 0.06+0.069 \cdot 0.06+0.01 \cdot 0.05=0.01410$

For the calculation of the average life of the part (Dm), the relation (9) is applied, obtaining the value of 5.7 years. 


\section{CONCLUSIONS}

The main stages specific to the preventive-planned maintenance developed in the paper consisted in elaborating the maintenance plan, establishing the optimal time to replace the machine tools, choosing the optimal type of machine tool and establishing the random wear elements of the machine tools. A. Kaufman's model was used to determine the optimal time to replace an injection machine, a model that takes into account the cost of maintenance and repairs, the purchase value of the machine, considering as the optimal time to replace the year in which the costs of injection. maintenance and repairs exceed the updated cost of acquisition, maintenance and repair. The optimal type of injection molding machine that will be chosen to replace the $T_{10}$ injection molding machine is $\mathrm{T}_{14}$, as it has a minimum average cost of purchase, maintenance and repair, respectively $42.286 \mathrm{UV}$.

\section{REFERENCES}

1. Mazurchevici S-N., Quadrini F., Nedelcu D., (2018), The liquid wood heat flow and material properties as a function of temperature, Materials Research Express 5 (3), 035303

2. Broitman E., Nedelcu D., Mazurchevici S-N., Glenat H., Grillo S., Tribological and nanomechanical behavior of liquid wood, Journal of Tribology 141 (2), 022001

3. https://www.starlubricants.ro/despre-noi/stiri/2016/07/28/9-pasi-pentru-intretinerea-masinilor-de-injectiemase-plastice, accessed on 12.05.2021

4. https://www.afahc.ro/ro/facultate/cursuri/luculescu/6.\%20Mentenanta\%20si\%20mentenabilitate.pdf, accessed on 29.03.2021

5. https://www.creeaza.com/referate/management/Metoda-ABC387.php, accessed on 12.05.2021

6. https://kodosurvey.com/blog/kaufmans-model-learning-evaluation-key-concepts-and-tutorial, accessed on 12.05.2021

7. Fradinho J., Nedelcu D., Gabriel-Santos A., Gonçalves-Coelho A., Mourão A., (2015), Some trends and proposals for the inclusion of sustainability in the design of manufacturing process, IOP conference series: Materials science and engineering 95 (1), 012142.

Received: August 27, 2021 / Accepted: December 15, 2021 / Paper available online: December 20, 2021 ( International Journal of Manufacturing Economics and Management. 